\title{
Effect of tillage and nutrient management on seed cotton yield and nutrient content of cotton
}

\author{
N. S. WAGH, R. N. KATKAR AND N. S. SADANSHIV
}

MEMBERS OF RESEARCH FORUM:

Corresponding author :

N.S. WAGH, Department of Soil

Science and Agricultural Chemistry,

Dr. Panjabrao Deshmukh Krishi

Vidyapeeth, AKOLA (M.S.) INDIA

Co-authors :

R. N. KATKAR, Department of Soil Science and Agricultural Chemistry, Dr. Panjabrao Deshmukh Krishi Vidyapeeth, AKOLA (M.S.) INDIA

N. S. SADANSHIV, National Bureau of Soil Survey and Land Utilisation Planning, NAGPUR (M.S.) INDIA
Received : 29.10.2017; Revised : 20.11.2017; Accepted : 28.11.2017

\section{Summary}

The field experiment was conducted to study the effect of integrated nutrient management on soil quality and cotton productivity under different tillage practices in vertisol at the Research Farm, Department of Soil Science and Agricultural Chemistry, Dr. Panjabrao Deshmukh Krishi Vidyapeeth, Akola.The treatments thus, involved two main treatments and eight sub treatments. The experiment main plot comprises of two treatments i.e. conservation tillage (CNS) and CNV. The seed cotton yield was slightly higher under conservation tillage as compared to conventional tillage. Highest seed cotton yield was recorded in the treatment receiving $100 \%$ $\operatorname{RDF}\left(60: 30: 30 \mathrm{NPK} \mathrm{kg} \mathrm{ha}^{-1}\left(15.57 \mathrm{q} \mathrm{ha}^{-1}\right)\right.$ followed by $50 \% \mathrm{RDF}+50 \% \mathrm{~N}$ (FYM) $\left(14.84 \mathrm{q} \mathrm{ha}^{-1}\right)$. The macronutrient content was noticed higher in conservation tillage as compared to conventional tillage at square, boll development and harvest stage. The content of N, P and $\mathrm{K}$ was observed higher in reproductive parts than that of leaves and stem. Further, it was also observed that the N, P and K content decreased from square initiation to boll development stage in reproductive parts, leaves and stem as the age of the cotton advances towards maturity. The nitrogen content pooled data indicated that 3.08 to $3.10,2.78$ to 2.79 and 1.77 to 1.80 per cent during square initiation stage of study whereas in the boll development stage it ranged from 2.18 to $2.20,1.88$ to 1.89 and 1.37 to 1.40 per cent and in the harvest stage it ranged 1.54 to $1.56,1.28$ to 1.29 and 1.11 to 1.14 per cent in reproductive parts, leaves and stem, respectively.

Key words : Tillage, Nutrient management, Nutrient content, Yield

How to cite this article : Wagh, N.S., Katkar, R.N. and Sadanshiv, N.S. (2017). Effect of tillage and nutrient management on seed cotton yield and nutrient content of cotton. Asian J. Soil Sci., 12 (2) : 338345 : DOI : 10.15740/HAS/AJSS/12.2/338-345. 